Review Article

\title{
Shweta Pradara - A Localised Symptom of the Female Reproductive System or a Systemic Disease? - A Review
}

\author{
Urvija', Sharon Samuel ${ }^{2}$
}

${ }^{13}$ Year P.G. Scholar, ${ }^{2}$ Associate Professor, Department of Prasuti Tantra \& Stree Roga, Sri Sri College of Ayurvedic Science \& Research Hospital, Bangalore, Karnataka, India.

DOI: https://doi.org/10.24321/2394.6547.202011

I $\quad \begin{array}{llll}\mathbf{N} & \mathbf{F} & \mathbf{O}\end{array}$

\section{Corresponding Author:}

Urvija, Department of Prasuti Tantra \& Stree Roga, Sri Sri College of Ayurvedic Science \& Research Hospital, Bangalore, Karnataka, India. E-mail Id:

urvijajgd15@gmail.com

Orcid Id:

https://orcid.org/0000-0003-3297-2595

How to cite this article:

Urvija, Samuel S. Shweta Pradara - A Localised Symptom of the Female Reproductive System or a Systemic Disease? - A Review. J Adv Res Ayur Yoga Unani Sidd Homeo 2020; 7(3\&4): 31-36.

Date of Submission: 2020-12-14

Date of Acceptance: 2020-12-28

\section{$\begin{array}{llllllllllll}\mathbf{A} & \mathbf{B} & \mathbf{S} & \mathbf{T} & \mathbf{R} & \mathbf{A} & \mathbf{C} & \mathbf{T}\end{array}$}

Shweta pradara is a pathological condition that is characterised by a localised symptom that is whitish discharge from the vaginal canal. The following are three criteria of leucorrhoea. 1) Excess secretion is evident from persistent vulvar moistness or staining of the undergarments or need to wear a vulvar pad, 2) It is non-purulent and non-offensive, 3) It is non-irritant and never causes pruritis, treatment of which includes to improvise the general health condition along with other specific management. Shweta pradara closely resembles leucorrhoea but does not completely fulfil the criteria. It has been explained mainly as a symptom in many diseases related to stree roga as well as prasuti tantra. Treatment options involve oral medications along with other lines of treatment like basti, lepa, varti, prakshalana and pichu. This indicates that the condition is more than just local. Very less has been explored about the systemic involvement in Shweta pradara which can be attempted to be established as the systemic disease as the acharyas have mentioned a separate classical treatment in order to combat the ailment, else can be understood as an important symptom of an underlying cause so as to attain symptomatic relief. Interpretation of Shweta pradara as a disease has been dealt in the article.

Keywords: Leucorrhoea, Localised Symptom, Systemic Disease, Moniliasis, Anaemia, Diabetes, Hyperglycemia, Shweta pradara, Stree Roga, Prasuti Tantra, Yoni Vyapat, Prameha, Panduroga

\section{Introduction}

Shwetapradara is one of the common complaints for which women seek help from gynaecologists. It not only occurs by the dysfunction of the reproductive system but also due to certain abnormality in general health in certain cases. ${ }^{3}$ Out of 10 women in the OPD of Sri Sri Ayurveda Hospital, Bangalore, come with the complaint of white discharge per vagina. Among these, 2 are known to have an underlying systemic disease. The recurrence rate is often present in these cases, if only managed locally.

Leucorrhoea is physiological in a healthy female during her puberty, menstrual cycle, pregnancy and during sexual excitement. Pathologically, there can be cervical or vaginal involvement. ${ }^{1}$ Here the matter of concern is when the patient's day to day activity is hampered due to the discharge. It is characterized by white discharge per vagina 
with or without foul smell, itching and pruritus, associated with problems like low back pain, lower abdomen pain, mental stress, sexual anxiety and local discomfort.

Shwetapradara has been mentioned in the classics as a symptom of the streerogas that occur due to vitiation of kapha and vata-kapha. ${ }^{2}$ Medicines prescribed by the various acharyas are Kashaya rasa yukta, which possess sthambhana action. ${ }^{3}$

\section{References of Shweta Pradara in the Ayurveda Classics}

The table 1 , below is a compilation of the references for Shweta pradara and vyadhis related to it.

Table I.References

\begin{tabular}{|c|c|c|c|}
\hline Charaka samhita & Chikitsa sthana 3 & ${ }^{\text {th }}$ chapter, Yonivyapat chiki & tsa adhyaya \\
\hline Condition & Nidana & Symptoms & Treatment \\
\hline $\begin{array}{l}\text { Kaphaja yoni } \\
\text { vyapat }\end{array}$ & $\begin{array}{l}\text { Kapha vardhaka } \\
\text { aahara vihara }\end{array}$ & Panduta of the Artava & $\begin{array}{l}\text { Ruksha and Ushna line of treatment } \\
\text { - } \quad \text { Basti with katu pradhana dravya mixed in } \\
\text { gomutra } \\
\text { - Kalka dharana of Shyama (trivrt) } \\
\text { - Varti of (i) a piece of cloth soaked in varaha } \\
\text { pitta } \\
\text { (ii) churna of yava and masha with saindhava } \\
\text { dipped in latex of arka - varti dharana for } \\
\text { kshana matra and then prakshalana with } \\
\text { sukhoshna } \\
\text { (iii) pippali, maricha, masha, shatahva, } \\
\text { kushta, saidhava }\end{array}$ \\
\hline $\begin{array}{l}\text { Sannipataja yoni } \\
\text { vyapat }\end{array}$ & $\begin{array}{l}\text { Samashana of } \\
\text { shad rasa }\end{array}$ & Shweta pichila vahini & $\begin{array}{l}\text { - Chikitsa told in vataja, pittaja, kaphaja, evam } \\
\text { dwandwaja yoni vyapat. } \\
\text { - Chikitsa given should be sadharana type }\end{array}$ \\
\hline $\begin{array}{l}\text { Upapluta yoni } \\
\text { vyapat }\end{array}$ & $\begin{array}{l}\text { Kapha vardhaka } \\
\text { aahara vihara by } \\
\text { garbhini, chardi } \\
\text { and shwasa } \\
\text { vega dharana }\end{array}$ & $\begin{array}{l}\text { Pandu sravan along with } \\
\text { toda and Shweta srava }\end{array}$ & $\begin{array}{l}\text { Dhatakyadi taila - for pichu, abhyanga } \\
\text { over kati, prushtha and trika pradesha, and } \\
\text { anuvasana basti } \\
\text { - Snehana - swedana to be done, followed by } \\
\text { santarpana with sneha pichu }\end{array}$ \\
\hline Kaphaja pradara & Gurvadi ahara & $\begin{array}{l}\text { Include pichila and pandu } \\
\text { varna yukta srava which } \\
\text { is described in detail to } \\
\text { be guru, pichila, ghana } \\
\text { srava. It causes manda } \\
\text { peeda, chardi, arochana, } \\
\text { hrillasa, shwasa and kasa }\end{array}$ & $\begin{array}{l}\text { - Pana-nimba and guduchi churna with } \\
\text { madya }\end{array}$ \\
\hline Shweta pradara & $\begin{array}{l}\text { Kapha vardhaka } \\
\text { aahara vihara }\end{array}$ & Shweta pradara & $\begin{array}{l}\text { - Rohitaka moola twak kalka along with jala for } \\
\text { oral intake } \\
\text { - } \\
\text { - jala for oral intake } \\
\text { - Amalaka churna/swarasa with madhu for } \\
\text { oral intake } \\
\text { - Nyagrodha (vata) twak kwatha with lodhra } \\
\text { for oral intake } \\
\text { - Vata twak kwatha for yoni pichu } \\
\text { - Plaksha twak churna with madhu made into } \\
\text { pinda form then into varti for yoni dharana } \\
\text { or pottali of churna } \\
\text { - Churna of lodhra, priyangu and yashtimadhu } \\
\text { (1 part each) with madhu is made into varti } \\
\text { for yoni dharana, after }\end{array}$ \\
\hline
\end{tabular}




\begin{tabular}{|c|c|c|c|}
\hline & & & $\begin{array}{l}\text { yoni abhyanga } \\
\text { Kashaya rasa pradhana dravya churna with } \\
\text { madhu for yoni dharana, after snehana of } \\
\text { yoni } \\
\text { - Abhyanga with vata nashaka taila, followed } \\
\text { by yoni dhupana with Sarala, guggulu, yava, } \\
\text { ghrita. } \\
\text { For complete cure of pandura asrgdara } \\
\text { - dhupana with sidhari matsyaka/katu } \\
\text { matsyaka (Chakrapani - shushka matsyaka) }\end{array}$ \\
\hline \multicolumn{4}{|c|}{ Sushruta Samhita ${ }^{5}$ Uttara tantra $38^{\text {th }}$ chapter, Yonivyapat pratisheda } \\
\hline $\begin{array}{l}\text { Kaphaja yoni } \\
\text { vyapat }\end{array}$ & $\begin{array}{l}\text { Kapha vardhaka } \\
\text { aahara vihara }\end{array}$ & $\begin{array}{l}\text { Pichila yoni, kandu yukta, } \\
\text { ati sheetala }\end{array}$ & \\
\hline Karnini yoni vyapat & $\begin{array}{l}\text { Vitiated kapha } \\
\text { along with rakta } \\
\text { forms mamsa } \\
\text { kandi }\end{array}$ & $\begin{array}{l}\text { shleshma linga } \\
\text { (shvaitata, paichilyata, } \\
\text { kandu) }\end{array}$ & - Varti - shodhana dravya \\
\hline $\begin{array}{l}\text { Acharana yoni } \\
\text { vyapat }\end{array}$ & $\begin{array}{l}\text { Maithuna } \\
\text { purva purushat } \\
\text { atirichyate }\end{array}$ & $\begin{array}{l}\text { Kapha vriddhi lakshanas } \\
\text { like shvaitata, paichilyata, } \\
\text { kandu }\end{array}$ & \\
\hline $\begin{array}{l}\text { Atichrana yoni } \\
\text { vyapat }\end{array}$ & $\begin{array}{l}\text { Excessive } \\
\text { indulgence in } \\
\text { the coital act }\end{array}$ & $\begin{array}{l}\text { shleshma linga } \\
\text { (shvaitata, paichilyata, } \\
\text { kandu) }\end{array}$ & \\
\hline $\begin{array}{l}\text { Atyananda yoni } \\
\text { vyapat }\end{array}$ & $\begin{array}{l}\text { kapha vardhaka } \\
\text { aahara vihara }\end{array}$ & shleshma linga (shvaitata) & \\
\hline \multicolumn{4}{|c|}{ Ashtanga sangraha $:$ Indu teeka, Uttara tantra $39^{\text {th }}$ chapter - Guhyarogapratishedha } \\
\hline $\begin{array}{l}\text { Kaphaja yoni } \\
\text { vyapat }\end{array}$ & $\begin{array}{l}\text { Abhishyandi aadi } \\
\text { ahara sevana }\end{array}$ & panduta of yoni & $\begin{array}{l}\text { - } \quad \text { Basti with katu pradhana dravya mixed in } \\
\text { gomutra } \\
\text { - Kalka dharana of shyama (trivrt) } \\
\text { - } \quad \text { Varti of (i) a piece of cloth soaked in varaha } \\
\text { pitta } \\
\text { (ii) churna of yava and masha with saindhava } \\
\text { dipped in latex of arka - varti dharana for } \\
\text { kshana matra and then prakshalana with } \\
\text { sukhoshna. } \\
\text { (iii) pippali, maricha, masha, shatahva, } \\
\text { kushta, saidhava }\end{array}$ \\
\hline $\begin{array}{l}\text { Upapluta yoni } \\
\text { vyapat }\end{array}$ & $\begin{array}{l}\text { kapha vardhaka } \\
\text { aahara vihara by } \\
\text { garbhini }\end{array}$ & Shweta pichchila vahini & $\begin{array}{l}\text { - } \quad \text { Vatanashaka ahara prayoga } \\
\text { - } \quad \text { Pichu - Sallaki, jingini, jambu, dhava and } \\
\text { panchavalkala Kashaya sadhita Sneha }\end{array}$ \\
\hline Acharana & $\begin{array}{l}\text { Maithuna } \\
\text { purva purushat } \\
\text { atirichyate }\end{array}$ & $\begin{array}{l}\text { Kapha vriddhi lakshanas } \\
\text { like shvaitata, paichilyata, } \\
\text { kandu }\end{array}$ & $\begin{array}{l}\text { - } \quad \text { Uttara basti - with taila } \\
\text { - } \quad \text { Pichu - cloth dipped in Go pitta or matsya } \\
\text { - } \quad \text { Pichu - Sallaki, jingini, jambu, dhava and } \\
\text { panchavalkala Kashaya sadhita Sneha }\end{array}$ \\
\hline \multicolumn{4}{|c|}{ Kashyapa Samhita7: Kalpa sthana, chapter-Revatikalpadhyaya } \\
\hline Jataharini & $\begin{array}{l}\text { Infliction by } \\
\text { jataharini }\end{array}$ & $\begin{array}{l}\text { srava that has been } \\
\text { mentioned refers to } \\
\text { Shweta pradara }\end{array}$ & Same as that of shweta pradara \\
\hline
\end{tabular}




\begin{tabular}{|c|c|c|c|}
\hline $\begin{array}{l}\text { Kaphaja yoni } \\
\text { vyapat }\end{array}$ & $\begin{array}{l}\text { kapha vardhaka } \\
\text { aahara vihara }\end{array}$ & sa pandure & $\begin{array}{l}\text { - Varti - pippali, maricha, masha, shatahva, } \\
\text { kushta, saidhava } \\
\text { - Pathya-taila, seedhu, yavanna and } \\
\text { abhayarishta }\end{array}$ \\
\hline \multicolumn{4}{|l|}{ Chakrapani dutta9: } \\
\hline Shweta pradara & $\begin{array}{l}\text { Excessive coitus, } \\
\text { abortions, } \\
\text { improper } \\
\text { hygiene, } \\
\text { improper diet } \\
\text { during bleeding } \\
\text { phase }\end{array}$ & $\begin{array}{l}\text { pandure pradare iti } \\
\text { Shweta pradara }\end{array}$ & $\begin{array}{l}\text { - Treatment told by Charaka with respect to } \\
\text { shweta pradara }\end{array}$ \\
\hline
\end{tabular}

\section{Discussion}

Table 1, compiles the references that we find in the classics in relation to Shweta pradara, which mostly depict it as a symptom to various gynaecological disorders. Understanding Shweta pradara as a symptom to another systemic disease or a systemic disease itself is going to provide the practitioners a broader perspective of treatment. Below mentioned are a few examples for the above mentioned outlook.

1. Shweta pradara as a symptom of an underlying systemic disease

Shweta pradara can be analysed to be a localised symptom of a systemic disease. Here, the importance to know about it, lies in the mode of management. In such conditions, if only locally treated yields an unsatisfying and incomplete result, hence leading to an increased incidence of recurrence and further deterioration in general health condition. Here are a few examples of systemic health conditions where in Shweta pradara can be noticed as a symptom.

\section{Prameha}

Prameha and Shweta pradara both are the diseases resulting from dushana of kapha dosha,,$^{10}$ the nidana in both the diseases is kaphavardhaka ahara-vihara. The sthanasamshraya of both diseases are very closely associated anatomically which is basti in prameha and yoni in Shweta pradara.

Charaka while explaining kaphaja prameha talks about the ghanata and shuklata of the mutra, ${ }^{11}$ here this ghanata and shuklata of the mutra can also be considered as Shweta pradara.

Yogaratnakara has also given the treatment of Shweta pradara under the chapter named Somaroga chikitsa.

With special reference to Diabetes and Leucorrhoea:

- Diabetes is considered as hyperglycemic state.

- While explaining leucorrhoea it is mentioned that the white discharge may be associated with pruritus in patients with history of diabetes and is diagnosed as moniliasis. ${ }^{12}$

- Moniliasis is caused by fungus monilia, now commonly known as candida albicans.

- High levels of sugar in blood and urine are directly proportional to the growth of the above mentioned fungus which is leading to localised symptoms. ${ }^{13}$

In the above condition the localised treatment might give relief for a very short duration of time as the underlying cause, which is, hyperglycemia has to be controlled primarily, which inturn will relieve the vaginal irritation.

\section{Panduroga}

Panduroga is explained by the dushana of rasa dhatu resulting in kshaya of uttarotara dhatus and upadhatu. The alpata of rakta dhatu mainly resulting in panduroga. Artava being an upadhatu of rasa dhatu is seen to have depleted as well. This depletion of artava can be considered as the depletion of the kshudha artava lakshanas. The disease pandu may also result in the panduta of the artava as explained above. The considerate treatment of pandu results in vriddhi of the depleted dhatus and upadhatus thereby relieving the shwetata or panduta of the artava.

With special reference to Anaemia and Leucorrhoea:

- Anaemia is the condition wherein the Haemoglobin levels are found to be at the lower end.

- In explanation of leucorrhoea, ill health and poor nutrition has been mentioned to be causing vaginal discharge. ${ }^{14}$

- Anaemia is directly associated to cause ill health and is due to poor nutrition.

- It causes exfoliation of the superficial cells leading to discharge from vaginal canal. ${ }^{15}$

2. Shweta pradara - a systemic disease:

To substantiate Shweta pradara as a systemic disease in itself, the following nidana panchaka has been interpreted. The diagnosis through investigations is mainly through an 
elimination method, wherein the tests are negative for underlying causes lead to the diagnosis of Shweta pradara as a systemic disease.

Nidana: kaphaja ahara vihara evam vataja ahara vihara like asatmya ahara, atyashana, vishamashana, alpashana, dushtabhojana, excessive coitus, abortion, improper mode of life and dietetics during the rajasrava kala, unhygiene.

Purvaroopa: generalised weakness.

Roopa: discharge per vagina (white, yellowish white), weakness, may or may not have pruritus.

Samprapti: The above mentioned nidana leads to the vitiation of vata and kapha dosha, rasa dhatu. Figure 1 describes the same.

Chikitsa: mentioned earlier according to various acharyas.
The systemic diseases like prameha, pandu in general can also be evaluated wherein the Shweta pradara can be one of the features. The systemic disease when only symptomatically treated has more chances of relapse.

Shweta pradara itself can be considered a systemic disease as interpreted in the samprapti above. It is important to know the disease for its systemic or local involvement for its treatment protocol. The necessity is strengthened by the presence of the management of Shweta pradara separately in the classics.

Shweta pradara if only a symptom, then the presence of separate treatment in the classics can signify its severity.

Acharyas have given various oral medications which also act systematically in curing the disease which is causing the Shweta pradara.

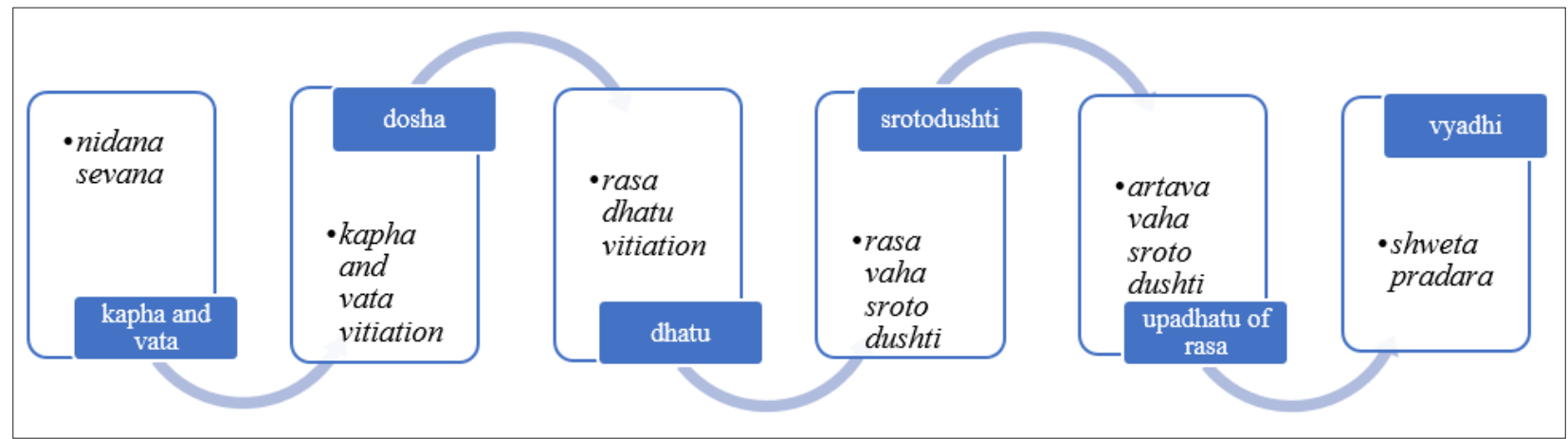

\section{Conclusion}

Leucorrhoea is closely related to Shweta pradara. Shweta pradara can be widely understood wherein leucorrhoea has restricted criteria. The pathology of leucorrhoea involves vaginal and cervical causes which has to be specifically examined and treated.

The mode of action of the oral medication is not restricted to reach to relieve the kha vaigunya in localised organ, but the kha vaigunya in the entire system.

Shweta pradara has been repeatedly found as a symptom in various diseases. Some patients come with complaint of severe white discharge overshadowing the underlying disease. Hence, careful history taking and examination will help in securing correct diagnosis. Also, in contrast, it is not always necessary for the underlying disease to be present. In these cases it can be a localised pathology, wherein the local treatments relieve the discomfort.

Pandu varna has been told by acharyas along with qualities of yoni vyapat which state pandu, pichila, kandu grasta etc. Here the panduta of the artava might be the white coloured mucus along with artava that is expelled or the artava itself is pandu in colour which means lesser red or pinkish in colour.
Keeping this in mind we also need to consider that not all pradara of shweta varna can be considered to be associated with systemic disease. Careful history taking, lab investigations will give a clear picture.

Evaluation of Shweta pradara as a systemic disease is important for attaining the health of the patient, the disease if locally treated without evaluating the systemic cause there are major chances of relapse and failure in the treatment.

\section{Conflict of Interest: None}

\section{References}

1. Konar H, Dutta's DC. Textbook of Gynaecology, Chapter no.34, $7^{\text {th }}$ Edition, Jaypee Publication, p-457.

2. Tiwari P. Ayurvedeeya Prasuti tantra evam Streeroga, Dwiteeyabhaga, Chapter no. 4, $2^{\text {nd }}$ Edition, Chaukambha Orientalia, p-267.

3. Tiwari P. Ayurvedeeya Prasuti tantra evam Streeroga, Dwiteeyabhaga, Chapter no. 4, $2^{\text {nd }}$ Edition, Chaukambha Orientalia, p-268.

4. Mishra AS, Samhita C, Sthana C, Chapter no.30, Edition [2019], Chaukambha Orientalia, p-800-817.

5. Kaviraj, Shastri AD, Samhita S, tantra U, Chapter no.38, Edition [2015], Chaukhambha Sanskrit Sansthan Publication, p-203-206. 
6. Mitra J, Sangraha A, teeka I, Tantra U, Chapter no.39, 6th Edition, Chaukambha Sanskrit Series Office, p-835836.

7. Nepal Rajguru Pandit Hemaraja Sharma, Kashyapa Samhita, Vrddhajivakiya tantra, Kalpa sthana, ChapterRevatikalpadhyaya, Edition [2019], Chaukhambha Sanskrit Sansthan Publication, p-290.

8. Pandit Sadasiva Sastri Joshi, Yogaratnakara, Vaidyakagrantha, Chapter-Streerogaadhikara, Edition [1939], Chaukhambha Sanskrit Sansthan Publication, p-750-753.

9. Acharya Siddhinandan Mishra, Charaka Samhita, Chikitsa sthana, Chapter no.30, Chakrapani commentary, Shloka - 116, Edition [2019], Chaukambha Orientalia, p-817-818.

10. Acharya Siddhinandan Mishra, Charaka Samhita, Chikitsa sthana, Chapter no.6, Edition [2019], Chaukambha Orientalia, p-183.

11. Acharya Siddhinandan Mishra, Charaka Samhita, Chikitsa sthana, Chapter no.6, Edition [2019], Chaukambha Orientalia, p-185.

12. Hiralal Konar, D.C.Dutta's Textbook of Gynaecology, Chapter no.34, $7^{\text {th }}$ edition, Jaypee Publication, p-457.

13. Hiralal Konar, D.C.Dutta's Textbook of Gynaecology, Chapter no.34, $7^{\text {th }}$ edition, Jaypee Publication, p-457.

14. Hiralal Konar, D.C.Dutta's Textbook of Gynaecology, Chapter no.34, $7^{\text {th }}$ edition, Jaypee Publication, $\mathrm{p}-457$.

15. Hiralal Konar, D.C.Dutta's Textbook of Gynaecology, Chapter no.34, $7^{\text {th }}$ edition, Jaypee Publication, $\mathrm{p}-457$. 